\section{Markus Glatz-Schmallegger}

www.valUse.at: Personnel - Management - Education Eisenstadt, Austria

\section{Edmond Byrne}

Process \& Chemical Engineering University College Cork, Ireland

\section{Gerard Mullally}

Department of Sociology and Criminology,

School of Society, Politics and Ethics

University College Cork, Ireland

\section{lan Hughes}

SFI MaREI Centre for Energy, Climate and Marine, Environmental Research Institute, University College Cork, Ireland

\section{Connor McGookin}

SFI MaREI Centre for Energy, Climate and Marine, Environmental Research Institute, University College Cork, Ireland

\section{Brian Ó Gallachóir}

SFI MaREI Centre for Energy, Climate and Marine, Environmental Research Institute, University College Cork, Ireland

\title{
SOCIAL INNOVATION AND DEEP INSTITUTIONAL INNOVATION FOR SUSTAINABILITY AND HUMAN DEVELOPMENT
}

\section{Introduction}

This paper by an international team around MaREI - the Science Foundation Ireland (SFI) national Research Centre for Energy, Climate and Marine research and innovation - builds on two previous papers. ${ }^{1}$ The underlying model of the

1st paper: I. Hughes, E. Byrne, M. Glatz-Schmallegger, C. Harris, W. Hynes, K. Keohane, B. Ó Gallachóir, Deep Institutional Innovation for Sustainability and Human Development (to be published 2021). 2nd paper: C. Harris, I. Hughes, Reimagining Democracy "deep institutional innovation" (DIIS) team posits that societal transformations occur at specific moments in history. It is the premise of the three papers that we are now at such a historical tipping point.

Climate change, environmental degradation and a biodiversity crisis, marked increases in inequality, economic crises, the rise of populism, rising geo-political tensions, the effects of increased globalisation, and ongoing religious and ethnic

in an Era of Deep Transition, "Irish Studies in International Affairs" (forthcoming). 
conflicts provide clear evidence that current social institutions are not optimal, either for human flourishing or for addressing global challenges. Meta-institutions around economics, culture, religion, education, politics (to name just a few) need to be fundamentally re-imagined. The coronavirus pandemic has brought this dangerous reality into even starker relief, as it highlights the interconnectedness and the sheer fragility of our globalised socio-economic-environmental system.

The authors draw on the models of Kellerman (2012) and Padilla et al. (2007). This triangular model of 'leaders-followers-context' emphasises the critical influence of societal and organisational context in affecting followers' demands and expectations and in empowering particular types of leaders. They describe that underlying changes in the dynamics lead to tipping points that necessitate systemic change. At such historical moments - and facing our present societal "wicked problems"2 accelerates such a dynamic - the prevalence of particular sources of toxicity, if they are not constrained, can tip the balance of the transformation to outcomes that are severely detrimental to the public good.

Based on specific essential functions, the team defines a "good" social institution that should be envisioned with its "re-imagining" as one that: (i) sets rules and norms of mass behaviour based predominantly on partnership values rather

2 H. Rittel, M. Webber, Dilemmas in a General Theory of Planning, "Policy Science" 1973, vol. 4, no. 2, pp. 155-169. than dominance values (ii) serves both to empower positive leaders (who are both ethical and effective), and constrain negative leadership, and (iii) enables progressive change towards solving the grand societal challenges facing humanity.

This third paper of the team on Deep Institutional Innovation for Sustainability and Human Development (DIIS) especially focusses on the need not only to re-imagine these institutions, but also to transform, and re-build them and to initiate practical interventions to gain momentum for transition towards sustainability. This paper especially builds on Hughes et al. $(2020)^{3}$ to explore the interconnections between processes of thought leadership, such as the re-imagining of social institutions, and emerging practices of social innovation that can have positive impact on the systemic architecture of those social institutions.

Sustainability transitions go well beyond mere technological change. Such transitions involve fundamental societal transformation processes, in which new technologies have to be combined with new forms of mobility, housing, work, economy, cooperation, and of time- and spatial-designs. ${ }^{4}$ In other words, social innovations of various kinds. This, in

I. Hughes, E. Byrne et al., Deep Institutional Innovation for Sustainability and Human Development, SFI MaREI Centre for Energy, Climate and Marine, Environmental Research Institute, University College Cork, Cork, Ireland 2020.

$4 \quad$ D. Loorbach et al., Sustainability Transitions Research: Transforming Science and Practice for Societal Change, "Annual Review of Environment and Resources" 2017, no. 42. 
turn, requires democratic legitimization of new and sustainable system architectures that succeed in fostering well-being and human flourishing - including the wellbeing of future generations.

This moment of deep transition, ${ }^{5}$ as well as being a time of danger, presents an opportunity for positive renewal. Or to put it like Carpenter et al.: "As fluctuations grow and instabilities appear there are increasing possibilities for major systemic transformations, not all of which are desirable." ${ }^{\prime 6}$ For positive renewal to occur out of this confluence of major crises, however, existing social institutions must not only be critiqued but fundamentally re-imagined, and alternative narratives must be proposed.

Such re-imagining requires a normatively argued "positive" vision for sustainability, ${ }^{7}$ from which such critical thinking takes its qualitative judgment. Like Ejderjan and others:" "this normative dimension supposes an ability to define a situation as undesirable

L. Kanger, J. Schot, Deep Transitions: Theorizing the Long-term Patterns of Socio-technical Change, "Environmental Innovation and Societal Transitions" 2019, no. 32, pp. 7-21.

6 S.R. Carpenter, C. Folke, M. Scheffer, F.R. Westley, Dancing on the Volcano: Social Exploration in Times of Discontent, "Ecology and Society" 2019, no. 24(1), p. 23, https:// doi.org/10.5751/ES-10839-240123 (accessed: 10.05.2021).

7 In the sense of J. Ehrenfeld, Sustainability by Design: A Subversive Strategy for Transforming Our Consumer Culture, Yale University Press, New Haven-London 2008.

8 O. Ejderjan et al., How Social Sciences and Humanities Can Contribute to Transformative Science, "GAIA - Ecological Perspectives on Science and Society" 2019, no. 28(2), pp. 160$162,161$. (unsustainable) and propose ways of developing towards a more desirable (sustainable) state." Contra a siloed perspective emanating from either a narrowly focussed technoscience or from neo-classical economics, such a conception is thus never "blind to the notion of values," but actively embraces same. We start with our normative positionings in the beginning of the following section. Then we build bridges from this foundation to socially innovative practices on different levels and in different sectors of society. Building on Giddens' structuration theory ${ }^{10}$ which states that social practices themselves can impact social institutions - in our line towards their requested positive re-imagining.

\section{Normative Framing for Deep Institutional Innovation}

In the 21st century the confluence of crises including the climate and biodiversity emergency shows that many foundational social institutions are suboptimal, either for the achievement of human flourishing or for addressing global challenges. This is the starting point for the effort to collect scholars from different disciplines and countries in a team on Deep Institutional Innovation for

9 G. Mullally et al., Disciplines, Perspectives and Conversations [in:] E. Byrne, G. Mullally, C. Sage (eds.), Transdisciplinary Perspectives on Transitions to Sustainability, Routledge, London-New York 2017, p. 36.

10 A. Giddens, The Constitution of Society, University of California Press, Berkeley/Los Angeles 1984. 
Sustainability and Human Development (DIIS ${ }^{11}$ ) around MaREI. ${ }^{12}$

The DIIS team has already produced in its short introductory phase 1 in 2020 two foundational scientific papers and diverse conference presentations, videos, articles and blogs. ${ }^{13}$ These last products represent the projects' strategic goal to initiate a vivid public debate on transition towards sustainability. And the team already has far proceeded in constructing the foundation for a longerterm project phase 2 with many additional formats aiming at fostering the public discourse on sustainability and human development.

With the first foundational paper the team states that meta-institutions around economics, culture, religion, education, politics (to name just a few) need to be fundamentally re-imagined. Following Eisler and Fry (2019) Hughes, Byrne et al. $(2021)^{14}$ argue that such re-imagining needs to be based on a shift in the underpinning values that animate the major social institutions that make up society: from dominance values of hierarchy, inequality, coercion and private gain, towards partnership values of equity, cooperation, and public good. This is being

11 A full description of the project can be found on: https://www.marei.ie/project/diis/ (accessed: 6.05.2021).

12 A short project-description can be found in a video, including a wording about the DIIS team by the President of the Republic of Ireland, Michael D. Higgins: https://www. youtube.com/watch? $\mathrm{v}=$ imGQZQeKFsI\&feature=youtu.be (accessed: 6.05.2021).

13 Most of them to be viewed at: https://www. marei.ie/project/diis/ (accessed: 6.05.2021).

14 I. Hughes, E. Byrne et al., Deep Institutional Innovation ..., op. cit. further elaborated in the second paper on democracy by Harris, Hughes (2020). ${ }^{15}$

In the context of today's grand societal challenges, the team adopts in both papers an explicitly normative approach by considering 'positive' transformation to be in the direction of advancing towards the goals of sustainability and human flourishing as reflected in the Paris Agreement on Climate Change and the United Nations Agenda 2030 with the Sustainable Development Goals. The papers' normativity is thus also grounded in well-established international agreements and laws.

The third paper of the DIIS team which is mainly discussed in this article - aims to supplement the perspective of Hughes, Harris, Byrne et al. by exploring the contribution that Sen's capabilities approach ${ }^{16}$ can make to the normative basis of re-imagining social institutions. This is an approach with deep roots. According to Aristotle the ultimate purpose of ethics is to guide action. In his economic thoughts, ${ }^{17}$ for example, the end of 'oikonomia' is to provide material goods for a succeeding life and well-being as ethical goal. Prosperity is not to be maximised for its

15 C. Harris, I. Hughes, Reimagining Democracy..., op. cit.

16 A. Sen, Capability and Well-Being [in:] A. Sen, M. Nussbaum (eds.), The Quality of Life, Clarendon Press, Oxford 1993, pp. 30-53.

17 For example: Aristoteles, Politik I, 1258b, zit. n. O. Höffe, Aristoteles (2006). As interpreted in: P. Ulrich, Lebensdienliche Marktwirtschaft [in:] Th. Bausch, D. Böhler, H. Gronke, Th. Rusche, M. Stitzel, M. Werner (eds.), Zukunftsverantwortung in der Marktwirtschaft. Festschrift für Hans Jonas, Lit, Münster 2000, p. 73. 
own sake (= 'chrematistics'), but instead as a means to pursue an individually and socially valued "good" life. ${ }^{18}$

\section{Economy and well-being}

From Aristotle to Adam Smith, economy was framed as a specific area of acting with the purpose to organize well-being. Today, a very vibrant debate reconfirms this line of thinking and states that economy should serve a fundamental function for organizing well-being - and not the other way round: Well-being of the many - including future generations cannot be sacrificed for the "normatively forcing necessities" of economic growth, which tends to serve unlimited "wants" of a few, considering its "externalized" negative costs for environment, climate, justice and many other fundamental aspects of well-being.

Of the many concepts of well-being, we especially consider Amartya Sen and Martha Nussbaum. Sedmak for example qualifies, that Sen and Nussbaum coincide in their core concept that a "good life" is based on the fundamental freedom to choose from real agency options or "capabilities" and to act hereby

18 Sustainability by Design: A Subversive Strategy for Transforming Our Consumer Culture, Yale University Press, New Haven-London 2008. Glatz-Schmallegger, Soziale Innovationen und ein ,Gutes Leben “ für alle [in:] M. Glatz-Schmallegger, J. Eurich (eds.), Soziale Dienste entwickeln. Innovative Ansätze in Diakonie und Caritas. Ein Studien- und Arbeitsbuch, Ev. Verlagsanstalt, Leipzig 2019, pp. 15-43. according to personally valued criteria. ${ }^{19}$ Both are reflecting measures, values and principles to be applied to one's own life. Here the basic advantages of the concept are lying, too: its multiple dimensionalities, commitment to pluralism, compatibility to other actual discourses like the ones on human rights and resilience.

But the differences between Sen and Nussbaum are starting at this very point, too. Without space to discuss this more in detail here one could say that they have different viewpoints on how to come from individual to societally binding concepts of a "good life" and acknowledging societies' pluralism at the same time - one of the "grand" discourses in philosophy. In short Nussbaum argues for a consensus on a list of materially framed basic capabilities whereas Sen argues for a necessary public debate in which capabilities must be materially defined for a certain context, setting or frame. ${ }^{20}$ Of course, there are many other concepts available, too. ${ }^{21}$

Sen and Nussbaum, following a well-argued concept of "freedom" themselves, ${ }^{22}$ became engaged in an intensive criticism of specific forms of lib-

19 Sedmak in: G. Graf et al., Der Capability Approach und seine Anwendung, Fähigkeiten von Kindern und Jugendlichen erkennen und fördern, VS Springer, Wiesbaden 2013, Einleitung: Zu ,Enactment “ und Inkulturation des Fähigkeitenansatzes, p. 20.

20 Leßmann in: ibidem, pp. 27-31.

21 Leßmann here discusses Alkires' and Robeyns' answers to this fundamental question.

22 A. Sen, Development as Freedom, 2nd ed., Oxford University Press, Oxford-New York 2001; M. Nussbaum, Gerechtigkeit oder das gute Leben, Suhrkamp, Frankfurt am Main 1999. 
eralism. Their common critique is based on liberalism's atomistic individualism and the way this has been woven into the neoliberal concepts of homo economicus and rational choice. Consumers are understood in this liberalist perspective as merely following rationalized self-interests against other self-interested individuals in a context of principally endless wants and limited resources. Other human needs do not gain relevance in this perspective.

In line with this, within energy and climate research to date, evidence of the dominance of this paradigm is also apparent. Van Vliet et al. found ${ }^{23}$ that in developing low carbon pathways, experts and academics tend to prioritize economic risks while other stakeholders consider political risks. This is further highlighted by the efforts to integrate social elements into what is a conventional technical field, having generally focused on behavioral aspects and individual energy choices. Sovacool et al. thus call for more research to reveal and understand how our existing social systems that perpetuate inequities (such as race, income or gender) are connected to contemporary sustainability challenges. ${ }^{24}$

Eisenstein $^{25}$ proposes that the necessary shift in values away from this

23 O. Van Vliet et al., Assessing Risks of Low-carbon Transition Pathways, "Environmental Innovation and Societal Transitions" 2020, no. 35, May.

24 B.K. Sovacool et al., Sociotechnical Agendas: Reviewing Future Directions for Energy and Climate Research, "Energy Research \& Social Science" 2020, vol. 70, p. 101617.

25 C. Eisenstein, Sacred Economics: Money, Gift, and Society in the Age of Transition, Penguin/ Random House, Berkeley 2011, p. 149. dominant economic paradigm that pushes us to focus on individual gain to a more collective society is akin to the maturing of an adolescent into an adult, noting that 'Just as life does not end with adolescence, neither does civilization's evolution stop with the end of growth. We are in the midst of a transition parallel to an adolescent's transition into adulthood'. As a young growing society our priorities are extrinsically (self-centered) orientated toward personal gain and growth. However, there is a need for us to mature beyond this economic paradigm of continuous growth and consumption. Instead, we must orientate ourselves toward intrinsic (greater than self) values such as fulfilment through interactions with others or the legacy of our existence.

Orientating our society toward these re-imagined values or goals requires a means of monitoring and assessing our progress. As outlined by Raworth while our planetary boundaries set outer limits for our growth and the consumption of resources, there is a minimal social floor that all people deserve such as clean water, access to education, food, etc. ${ }^{26}$

Thus, given the significant levels of inequality in our current society, the key focus for economic policy in the coming decades should be the redistribution of wealth as opposed to continuous growth, highlighting the need to perhaps consider alternatives to the commonly used measure of a country's success: gross domestic profit (or GDP). This is not

26 K. Raworth, A Doughnut for the Anthropocene: Humanity's Compass in the 21st Century, "The Lancet, Planetary Health" 2017, vol. 1, iss. 2, May 01, pp. E48-E49. 
to say we must do away with the use of GDP entirely but rather that it can no longer be the primary indicator to consider. Porter et al. - to refer to only one prominent example - have complied a series of well-being indicators (such as health, nutrition, inclusiveness, personal freedoms) that they call 'The Social Progress Index'. ${ }^{27}$ It explores the comparative strengths and weaknesses of a country against others with a similar GDP.

\section{Positive freedom}

Sen, Nussbaum and many other philosophers like Taylor also criticize neoliberal economics for primarily focusing on 'negative' freedom. For example, negative freedom as constraints from pressure from outside "economy," which is claimed to be following its own separate logic as a differentiated societal subsystem. Such liberalist concepts of negative freedom are in their view primarily seeking to enforce minimum regulation on economic actors.

Taylor $^{28}$ argues on the contrary for a positive concept of freedom, which he sees in the potential to follow qualitative goals for a flourishing life. Positive freedom in his understanding involves following qualitative goals of well-being and strengthening economic, societal and political institutions that fos-

27 M.E. Porter et al., Social Progress Index 2014, Social Progress Imperative, Washington, D.C. 2014.

28 C. Taylor, Negative Freiheit? Zur Kritik des neuzeitlichen Individualismus, Suhrkamp Taschenbuch Wissenschaft, Frankfurt am Main 1988. ter a conception of well-being that not merely equates with or emanates from quantitative growth.

This positive freedom to lead successful and qualitatively "good" lives in mutual relationship - including positive civil and social rights - is something Axel Honneth refers to in more detail. ${ }^{29}$ He envisages a positive freedom to articulate needs and capacities. This freedom requires mutual social recognition at its core. Honneth's view is less rooted in the rational interests of Kant, and more in socially and emotionally stabilized interrelations of reciprocal recognition.

On the other side of this dynamic are normatively biased struggles for mutually denied recognition. Such struggles, if taken up by social groups against other groups, provide a frame for interpreting feelings of violation and lack of recognition and can be used to gain moral standing and social influence in wider areas of society. Which we see in actual forms of right-wing extremism, in authoritarianism $^{30}$ or in similar phenomena - also in the center of western industrialized societies.

To foster the freedom for following positively and emotionally valued concepts of well-being, without defining what the meaning of well-being has to be materially for the individual, is the basis of Amartya Sens conception of freedom. Sen focusses on what such

29 A. Honneth, Kampf um Anerkennung. Zur moralischen Grammatik sozialer Konflikte, Suhrkamp Taschenbuch Wissenschaft, Frankfurt am Main 1994.

30 O. Decker et al., Flucht ins Autoritäre: Rechtsextreme Dynamiken in der Mitte der Gesellschaft, Psychosozial Verlag, Gießen 2018. 
a supportive frame would look like and he defines a function of economy to foster well-being, too. Sen is very critical of defining a societies' well-being or justice primarily in terms of its material wealth. Development needs a by far broader base than just quantitative measures. While working for the UN and developing UN's Human Development Index, Sen set about the task of measuring the various dimensions of well-being with appropriate indicators and key figures. He knew this requires an ethical-philosophical concept of well-being as much as economic indices and methods. His concept acknowledges that factors like gender, age, ethnicity and many other assets massively co-determine the potential that an individual can realize in a given context - even if all participants own the same material resources.

\section{Freedom and capabilities}

A realistic theory of justice should therefore focus on the real chances of individuals in a specific societal context to realize what they themselves value. Sen's concept of well-being therefore explicitly acknowledges the options individuals can actually choose from. The most important goal of a just society, in Sen's framing, is to provide real life-chances and options for persons in order to live a life they personally value and that they can reasonably expect to be socially acknowledged. (And what "reasonably expect" and "socially acknowledge" means has to be democratically negotiated).

As Sen states, "Social and economic factors such as basic education, elementary health care, and secure employment are important not only in their own, but also for the role they can play in giving people the opportunity to approach the world with courage and freedom. These considerations require a broader informational base; focusing particularly on people's capabilities to choose the lives they have reason to value." ${ }^{\prime 1}$

Sen's framing also explicitly recognizes that as well as differing from person to person, what is valued as a 'good life' is also culturally constructed and stabilized by political institutions. In this way there doesn't seem to be a simple way to swap one measure (like GDP - which doesn't even tell much about "well-being" as we saw) with other single measures. But there is good work going on for complexity-capable concepts that try to implement better measures that can tell us more about matters that really count for "well-being." 32

But up to now the path towards better measures had been messy and conflictive, new concepts have either lacked political legitimation or simply been unwanted by states that would have lost their actual good position by new measurements and new international rankings. Sen therefore stresses the necessity to identify "capabilities" qualitatively in a valuing dialogue, so that this concept can be applied to a specific problem and/or context and on this basis be framed into a new measurement. Such

31 A. Sen, Inequality Re-examined, Oxford University Press, Oxford-New York 1992, p. 81.

32 See the example of New Zealand, Netherlands as discussed in H. Lintsen et al., Well-being, Sustainability and Social Development. The Netherlands 1850-2050, Springer, Basel 2018. 
a procedure in dialogue thus acknowledges the plurality of legitimating power, values and lifestyles in modern differentiated societies.

In summary, well-being can be enhanced by expanding the capabilities of individuals to lead the kinds of lives they value and have reason to value in a certain social-economic and political context. The capabilities perspective focuses on the qualities of realization opportunities ("capabilities") that specific social arrangements open up or close for certain persons and groups. In so far as true chances of realizing valued choices exist, justice exists, too. The state's function is to empower citizens above a culturally and politically defined societal threshold so that they have real chances to realize their envisioned good life.

Sen's concept of well-being has been directly incorporated in the Human Development Index of the UN and has gained legitimated influence in the UN up to now. It has also been incorporated in the Stiglitz/Sen/Fitoussi - report to the EU commission from 2010 in order to more accurately measure the success and failures of political and economic programs. And it has become an indispensable basis for definitions of sustainable development, including the process that led to the U.N. Sustainable Development Goals (SDGs). In this way, a broader concept of well-being has been declared as the fundamental basis for development than a merely linear and quantitative understanding of "wealth", as measured by GDP. This is not to say we must do away with the use of GDP entirely but rather that it can no longer be considered in isolation and instead must be viewed in line with a range of alternative indicators for well-being and social vibrancy.

\section{Social Innovation and Deep Institutional Innovation}

Addressing societal problems through transformation requires an integrated approach of different forms of knowledge: ${ }^{33}$ orientation knowledge (in which direction transformation has to be oriented, towards which "good" causes and goals); systemic knowledge (as for example knowledge of the energy system and its interdependencies); as well as action knowledge (measures for transformation and their envisioned outcomes/ impacts).

And besides the necessity to integrate different forms of knowledge there is a methodological need to define the interdependency of theory and practice. As we know for our project Giddens' "structuration theory" works in both directions. This means for us, that we have to re-think social institutions that shape our behaviour on one hand, and at the same time work on "new," "better" and "sustainable" practices that help to transform failing institutions practically on the other hand.

Therefore, embedded in the concept of deep institutional innovation is an elaborated approach to "practices" framed here as "social innovations." The concept of social innovations in this

33 For example, B. Elzen, F.W. Geels, K. Green, System Innovation and the Transition to Sustainability: Theory, Evidence and Policy, Elgar, Cheltenham 2004. 
section is focused on transition research and grounded in a reflective ethical perspective on values such as equity, cooperation and public good ${ }^{34}$ and as elaborated with Sen/Nussbaum ${ }^{35}$ and based on Hughes, Byrne et al. (2021) $)^{36}$ above.

\section{MLP and System Change}

Our starting point are the research findings on the genesis of technology and, in particular, those approaches that tackle questions of system transition and sociotechnical system change (cf. Geels and Schot 2007).

Geels and Schot provide a multi-level approach to socio-technical system change which distinguishes between three levels: niche innovations, the sociotechnical regime and the sociotechnical landscape. They view 'transitions as outcomes of alignment between developments at multiple levels' or 'as changes from one sociotechnical regime to another.' ${ }^{37}$ At a conceptual level, however, the interlinkages of multiple levels of socio-technical structuration (such as the dynamic interplay of niches and regimes) and multiple socio-spatial scales of governance (such as the interplay of regional, national and international governance systems) are still the focus of research aimed at providing a convincing integration. ${ }^{38}$

34 Soziale Dienste entwickeln..., op. cit.

35 Ibidem.

36 Ibidem.

37 F.W. Geels, J.W. Schot, Typology of Sociotechnical Transition Pathways, "Research Policy" 2007, no. 36, p. 399.

38 P. Späth, H. Rohracher, Local Demonstrations for Global Transitions - Dynamics across
The multi-level model is also connected to an understanding of different temporal dimensions of change - from short-term processes at micro-level to the "longue durée" of changes at the macro-level of sociotechnical landscapes. At the meso-level of a "socio-technical regime", configurations are temporarily stabilized and supported by a rule set or "grammar" that structures the evolutionary process. "The regime incorporates the mutually reinforcing technological and institutional structures of specific domains, such as the energy system, and is characterized by a resistance to change (which, for example, may cause promising new technologies to fail)." 39

In this model, innovations that could potentially change the regime develop within niches. But transition can be originally initiated from all levels, niche, regime or landscape changes. Of particular relevance in the present context is the literature which emphasises how changes at the landscape level might destabilise a system and create a window of opportunity for the spread of niche innovations. This could lead to transformation and, ultimately, the institutionalisation of new social practices on all levels.

Governance Levels Fostering Socio-Technical Regime Change Towards Sustainability, "European Planning Studies" 2012, vol. 20, iss. 3: Places and Spaces of Sustainability Transitions: Geographical Contributions to an Emerging Research and Policy Field 461-479, p. 465.

39 Ibidem. 


\section{Defining Social Innovation}

According to Turnheim, so called "social innovations" are increasingly discussed as practices to overcome lock-in and path dependencies that prevent effective climate change and its governance. ${ }^{40}$

Social change in a scientific sense (for example demographic change) merely takes place and can therefore only be qualified ex post. But it is not necessarily the consequence of an intentional social process that seeks to improve the conditions of a group or population. By contrast, Howaldt and Schwarz ${ }^{41}$ define transformative social change as something that can, in principle, be shaped by society - 'by the actors and their innovations.' ${ }^{42}$ Thus, social innovation can become a central driver of intended social transformation.

Social innovation as a concept has gained high relevance within the agendas and programs of actors including the EU, national innovation programs, and private, social, educational actors, among others. Social innovation has become a key pillar of efforts to address the urgent need for solving social, economic, environmental and institutional

40 B. Turnheim et al., Innovating Climate Governance: Moving Beyond Experiments, Cambridge University Press, Cambridge 2018, p. 17.

41 J. Howaldt, R. Kopp, M. Schwarz, On the Theory of Social Innovations: Tarde's Neglected Contribution to the Development of a Sociological Innovation Theory, Beltz Juventa, Weinheim 2015.

42 Both referring to U. Schneidewind, Wandel verstehen-Auf dem Weg zu einer "Transformative Literacy" [in:] H. Welzer, K. Wiegandt (eds.), Wege aus der Wachstumsgesellschaft, Fischer Taschenbuch, Frankfurt am Main 2013, p. 123. problems through fundamental transformation.

Social innovations aim for gaining societal impact and to become incentives for steering societal change in a direction that can be marked as a "positive" one. As stated above, this has to be grounded in a transparent normative concept, such as Sen's concept of well-being through sustainable development.

Although there is not the one dominant definition for social innovations being a relatively nascent scientific agenda, the Young Foundation provides the following definition that has gained institutional influence, particularly within the EU Commission:

Social innovations are new solutions (products, services, models, markets, processes, etc.) that, simultaneously, satisfy social needs (more effectively than existing solutions). They create new or better capabilities and relationships and make better use of assets and resources. In other words, social innovations are good for society and improve society's capacity to act. ${ }^{43}$

Providing "better" answers and capabilities needs to be qualified. This has two main dimensions. First, "better" is connected to goals for societal development. In contrast to technological innovations, social innovations are directly connected to societal goals, towards which concrete innovations should help society to move. In our view, "better" in this paper refers to Amartya Sen's understanding

43 R. Murray et al., The Open Book of Social Innovation, ed. The Young Foundation, 2012, p. 18, https://youngfoundation.org/wp-content/uploads/2012/10/The-Open-Book-ofSocial-Innovationg.pdf(accessed: 6.05.2021). 
of well-being and development - social innovations help to realize capabilities for well-being in a society.

Second, "better" needs to be defined from the perspective of potential users. Social innovations have to prove to be better from the user's perspective. This implies the need to include potential users from the beginning in the process of developing a social innovation. Social innovations differ from prevailing routines, forms of thinking and acting and provide better answers to societal needs (first order). But they can also be framed as efforts to improve social relations and cooperation/institutionalization as part of how better answers to societal needs are being provided (second order).

For example, Rogge states that social innovation in the energy sector (SIE) means a combination of ideas, objects and/or actions that change social relations and involve new ways of doing, thinking and/or organising energy. And she provides an example: organising under cooperative principles the provision of renewable energy. ${ }^{44}$ Energy transition shall prove successful (and gaining acceptance), not only as wealth accumulating but as producing new forms of governance, as cultural innovation including life-styles, "prosuming" and new organizational forms for mobility. Thus, as important as the initial goals are the political concepts and institutional systems in which they become embedded.

44 K. Rogge, Social Innovation in Energy Transitions: Co-creating a Rich Understanding of the Diversity, Processes, Contributions, Success and Future Potentials of Social Innovation in the Energy Sector, April 2020, GA\#: 837498, project outline, p. 17.
In summary, social innovations are concrete societal practices for finding "new" (before), "better" (users) and "sustainable" (diffusion, innovations being accessible and affordable for potential users) answers to changing societal meta-problems like climate change. ${ }^{45}$ These three major criteria (new/better/ sustainable) serve here to define our concept of "social innovations." 46

\section{To be specified: Social Innovations and DIIS-theses}

The question the DIIS team aims to address in more detail will be how "thought leadership," in the form of re-imagining social institutions - as framed in the DIIS project ${ }^{47}$ - is related to social innovations, as framed here. This is within a context whereby new/better/sustainable social practices that are themselves changing the social institutions may be re-imagined towards more sustainable and fair system architectures.

We seek practices that help us to specify DIIS impacts like:

- Informing and shaping national and international dialogue

- National and international policy impacts informed by evidence-based inputs

45 As developed in more detail in: J. Eurich, M. Glatz-Schmallegger, A. Parpan-Blaser, Innovationen gestalten in Organisationen des Sozialwesens, VS Springer, Wiesbaden 2018.

46 As in: ibidem.

47 Besides the two above mentioned papers there is more information available on www.MaRei. ie (accessed: 6.05.2021). 
- Building and fostering national and international stakeholder alliances for transformative change that supports sustainability and human flourishing.

For both governance and innovation studies, the interest in experiments has ultimately been about how the concrete outputs of experiments may generate broader impact on the socio-technical systems which they address. "This may be through the adoption of ideas, through the translation of skills and capabilities or through a deeper reordering of norms and institutional rules and arrangements." 48

In the DIIS project we seek changes in forms of thinking that underpins our basic societal institutions because institutions have deep impact on our behaviour. But we approach such changes in thinking also by the potential changing momentum to be gained by social innovations. Because we know about the impact practices have on institutions. Re-thinking requires per se re-shaping and re-implementing, forms of acting in new/better/sustainable ways that help to change our institutions by practice.

\section{References}

Barry J., Bio-fuelling the Hummer: Transdisciplinary Thoughts on Techno-optimism and Innovation in the Transition from Unsustainability [in:] E. Byrne, G. Mullally, C. Sage (eds.), Transdisciplinary Perspectives on Transitions to Sustain-

48 B. Turnheim et al., Innovating Climate Governance..., op. cit., p. 12. ability, Routledge, London-New York 2017, pp. 106-123.

Bush P.D., Culture, Values and Institutions [in:] The Elgar Companion to Social Economics, 2nd ed., Edward Elgar Publishing, Cheltenham 2015.

Bush P.D., The Theory of Institutional Change, "Journal of Economic issues" 1987, no. 21(3), pp. 1075-1116.

Carpenter S.R., Folke C., Scheffer M., Westley F.R., Dancing on the Volcano: Social Exploration in Times of Discontent, "Ecology and Society" 2019, no. 24(1), https://doi.org/10.5751/ES-10839240123 (accessed 10.05.2021).

Cech E., Great Problems of Grand Challenges: Problematizing Engineering's Understanding of Its Role in Society, "International Journal of Engineering, Social Justice, and Peace" 2012, no. 1(2), pp. 85-94.

Decker O. et al., Flucht ins Autoritäre: Rechtsextreme Dynamiken in der Mitte der Gesellschaft, Psychosozial Verlag, Gießen 2018.

Dedeurwaerdere T., Sustainability Science for Strong Sustainability, Edward Elgar Publishing, Cheltenham 2014.

Ehrenfeld J., Sustainability by Design: A Subversive Strategy for Transforming Our Consumer Culture, Yale University Press, New Haven 2008.

Ejderjan O., Schneider F., Bornemann B., Kläy A., How Social Sciences and Humanities Can Contribute to Transformative Science, "GAIA - Ecological Perspectives on Science and Society" 2019, no. 28(2), pp. 160-162.

Eisenstein C., Sacred Economics: Money, Gift, and Society in the Age of Transition, Penguin/Random House, Berkeley 2011. Eisler R., Fry D.P., Nurturing Our Humanity: How Domination and Partnership Shape Our Brains, Lives, and Future, Oxford University Press, Oxford 2019. 
Elzen B., Geels F.W., Green K., System Innovation and the Transition to Sustainability: Theory, Evidence and Policy, Elgar, Cheltenham 2004.

Eurich J., Glatz-Schmallegger M., Parpan-Blaser A., Innovationen gestalten in Organisationen des Sozialwesens, VS Springer, Wiesbaden 2018.

Geels F.W., Schot J.W., Typology of Sociotechnical Transition Pathways, "Research Policy" 2007, no. 36, pp. 399-417.

George B., Authentic Leadership: Rediscovering the Secrets to Creating Lasting Value, John Wiley \& Sons, Hoboken 2003.

Giddens A., The Constitution of Society, University of California Press, Berkeley-Los Angeles 1984.

Girard R., Oughourlian J.M., Lefort G., Things Hidden since the Foundation of the World, A\&C Black, London-New York 2003.

Glatz-Schmallegger M., Soziale Innovationen und ein ,Gutes Leben” für alle [in:] M. Glatz-Schmallegger, J. Eurich (eds.), Soziale Dienste entwickeln. Innovative Ansätze in Diakonie und Caritas. Ein Studien- und Arbeitsbuch, Ev. Verlagsanstalt, Leipzig 2019, pp. 15-43.

Graf G., Kapferer E., Sedmak C., Der Capability Approach und seine Anwendung, Fähigkeiten von Kindern und Jugendlichen erkennen und fördern, VS Springer, Wiesbaden 2013.

Granovetter M., Economic Action and Social Structure: The Problem of Embeddedness [in:] M. Granovetter, R. Swedberg (eds.), The Sociology of Economic Life, Boulder, CO 1992, pp. 53-84.

Harris C., Hughes I., Reimagining Democracy in an Era of Deep Transition, "Irish Studies in International Affairs" (forthcoming).

Hickel J., Kallis G., Is Green Growth Possible? New Political Economy, pp. 1-18, https://doi.10.1080/13563467.2019.1598 964 (accessed: 6.05.2021).
Himmelweit S., Making Visible the Hidden Economy: The Case for Gender-impact Analysis of Economic Policy, "Feminist Economics" 2002, no. 8(1), pp. 49-70.

Hodgson G.M., On Defining Institutions: Rules versus Equilibria, "Journal of Institutional Economics” 2015, no. 11(3), pp. 497-505.

Hollander E.P., Offermann L., Power and Leadership in Organizations: Relationships in Transition, "American Psychologist” 1990, no. 45, pp. 179-189.

Honneth A., Kampf um Anerkennung. Zur moralischen Grammatik sozialer Konfikte, Suhrkamp Taschenbuch Wissenschaft, Frankfurt am Main 1994.

Howaldt J., Kopp R., Schwarz M., On the Theory of Social Innovations. Tarde's Neglected Contribution to the Development of a Sociological Innovation Theo$r y$, Beltz Juventa, Weinheim 2015.

Hughes I., Disordered Minds: How Dangerous Personalities are Destroying Democracy, John Hunt Publishing, AlresfordHampshire 2018.

Hughes I., Byrne E., Glatz-Schmallegger M., Harris C., Hynes W., Keohane K., Ó Gallachóir B., Deep Institutional Innovation for Sustainability and Human Development, SFI MaREI Centre for Energy, Climate and Marine, Environmental Research Institute, University College Cork, Cork, Ireland 2020.

Jackson T., The Post-growth Challenge: Secular Stagnation, Inequality and the Limits to Growth, CUSP Working Paper, https://timjackson.org.uk/the-postgrowth-challenge/ (accessed: 6.05.2021). Jasanoff S., The Ethics of Invention: Technology and The Human Future, Norton, New York 2016.

Kamola I., US Universities and the Production of the Global Imaginary, "The British Journal of Politics \& International Relations" 2014, no. 16, pp. 515-533. 
Kanger L., Schot J., Deep Transitions: Theorizing the Long-term Patterns of Socio-technical Change, "Environmental Innovation and Societal Transitions" 2019, no. 32, pp. 7-21.

Kay J., The Kay Review of UK Equity Markets and LongTerm Decision Making, HM Government, http://www.ecgi.org/ conferences/eu_actionplan2013/documents/kay_review_final_report.pdf (accessed: 6.05.2021).

Kellerman B., The End of Leadership, Harper Business, New York 2012.

Komlos J., Foundations of Real-World Economics, 2nd ed., Routledge, LondonNew York 2019.

Laybourn-Langton L., Jacobs M., Paradigm Shifts in Economic Theory and Policy. Intereconomics, "Review of European Economic Policy" 2018, no. 53(3), pp. 113118, https://archive.intereconomics.eu/ year/2018/3/paradigm-shifts-in-economic-theory-and-policy/ (accessed: 6.05. 2021).

Lazonick W., Profits without Prosperity, "Harvard Business Review" 2014, September, https://hbr.org/2014/09/profitswithout-prosperity (accessed: 6.05.2021).

Lintsen H., Veraart F., Smits J.P., Grin J., Well-being, Sustainability and Social Development: The Netherlands 1850-2050, Springer, Basel 2018.

Little A., Macdonald K., Pathways to Global Democracy: Escaping the Statist Imaginary, "Review of International Studies" 2013, no. 39(4), pp. 789-813.

Loorbach D., Frantzeskaki N., Avelino F., Sustainability Transitions Research: Transforming Science and Practice for Societal Change, "Annual Review of Environment and Resources" 2017, no. 42.

MacGregor Burns J., Transforming Leadership, Atlantic Monthly, New York 2003.

McGregor J.A., Pouw N., Towards an Economics of Wellbeing: What Would Economics Look Like If It Were Focused on Human Wellbeing?, "Cambridge Journal of Economics" 2017, no. 41(4), pp. 1123-1142.

Mullally G., Byrne E., Sage C., Disciplines, Perspectives and Conversations [in:] E. Byrne, G. Mullally, C. Sage (eds.), Transdisciplinary Perspectives on Transitions to Sustainability, Routledge, London-New York 2017, pp. 21-36.

Murray R., Caulier-Grice J., Mulgan G., The Open Book of Social Innovation, ed. The Young Foundation, 2012, https:// youngfoundation.org/wp-content/uploads/2012/10/The-Open-Book-of-SocialInnovationg.pdf (accessed: 6.05.2021).

Nesvetailova A., Shadow Banking: Scope, Origins and Theories, Routledge, London-New York 2019.

Nussbaum M., Gerechtigkeit oder das gute Leben, Suhrkamp, Frankfurt am Main 1999.

OECD, Beyond Growth, OECD Publishing, 2019.

OECD, OECD Economic Outlook, vol. 2019, iss. 1, OECD Publishing, 2019, https:// doi.org/10.1787/5713bd7d-en (accessed: 6.05.2021).

OECD, OECD Employment Outlook 2018, OECD Publishing, 2018, https://doi. org/10.1787/empl_outlook2018-en (accessed: 6.05.2021).

OECD, OECD National Accounts Statistics (database), 2019, https://doi.org/10.1787/ data-00619-en; https://doi.org/10.1787/ f54eea03-en (accessed: 6.05.2021).

OECD, The Future of Productivity, OECD Publishing, 2015, https:/www.oecd.org/ eco/OECD-2015-The-future-of-productivity-book.pdf (accessed: 6.05.2021).

OECD, Trust and Public Policy: How Better Governance Can Help Rebuild Public Trust, "OECD Public Governance Reviews" 2017, OECD Publishing, https:// doi.org/10.1787/9789264268920-en (accessed: 6.05.2021). 
OECD, Under Pressure: The Squeezed Middle Class, OECD Publishing, 2019, https://doi.org/10.1787/689afed1-en (accessed: 6.05.2021).

Ott M.R. (ed.), The Future of Religion: Toward a Reconciled Society, "Studies in Critical Social Sciences" 2007, no. 9.

Padilla A., Hogan R., Kaiser R.B., The Toxic Triangle: Destructive Leaders, Susceptible Followers, and Conducive Environments, "The Leadership Quarterly" 2007, no. 18(3), pp. 176-194.

Porter M.E., Stern S., Green M., Social Progress Index 2014, Social Progress Imperative, Washington, D.C. 2014.

Ravetz J.R., Post-normal Science and the Complexity of Transitions towards Sustainability, "Ecological Complexity" 2006, vol. 3, pp. 275-284.

Ravetz J.R., What Is Post-normal Science, "Futures" 1999, vol. 31, pp. 647-653.

Raworth K., A Doughnut for the Anthropocene: Humanity's Compass in the 21st Century, "The Lancet, Planetary Health" 2017, vol. 1, iss. 2, May 01, pp. E48-E49.

Rittel H., Webber M., Dilemmas in a General Theory of Planning, "Policy Science" 1973, vol. 4, no. 2, pp. 155-169.

Rogge K., Social Innovation in Energy Transitions: Co-creating a Rich Understanding of the Diversity, Processes, Contributions, Success and Future Potentials of Social Innovation in the Energy Sector, April 2020, GA\#: 837498, project outline.

Rost J.C., Leadership for the Twenty-first Century, Greenwood Publishing Group, Boston 1991.

Sandel M.J., Market Reasoning as Moral Reasoning: Why Economists Should Re-engage with Political Philosophy, "Journal of Economic Perspectives" 2013, no. 27(4), pp. 121-40.

Sandel M.J., What Money Can't Buy: The Moral Limits of Markets, Penguin Books, London 2012.
Schneidewind U., Wandel verstehen - Auf dem Weg zu einer "Transformative Literacy” [in:] H. Welzer, K. Wiegandt (eds.), Wege aus der Wachstumsgesellschaft, Fischer Taschenbuch, Frankfurt am Main 2013, pp. 115-140.

Sen A., Capability and Well-Being [in:] A. Sen, M. Nussbaum (eds.), The Quality of Life, Clarendon Press, Oxford 1993, pp. 30-53.

Sen A., Development as Freedom, 2nd ed., Oxford University Press, Oxford-New York 2001.

Sen A., Inequality Re-examined, Oxford University Press, Oxford-New York 1992.

Shiller R.J., Narrative Economics: How Stories Go Viral and Drive Major Economic Events, Princeton University Press, Princeton-Oxford 2019.

Smiler A., Is Masculinity Toxic?, Thames and Hudson, London 2019.

Sovacool B.K., Hess D.J., Amir S., Geels F.W., Hirsh R., Medina L.R., Miller C., Palavicino C.A., Phadke R., Ryghaug M., Schot J., Sociotechnical Agendas: Reviewing Future Directions for Energy and Climate Research, "Energy Research \& Social Science" 2020, vol. 70, p. 101617.

Späth P., Rohracher H., Local Demonstrations for Global Transitions - Dynamics across Governance Levels Fostering Socio-Technical Regime Change Towards Sustainability, "European Planning Studies" 2012, vol. 20, iss. 3: Places and Spaces of Sustainability Transitions: Geographical Contributions to an Emerging Research and Policy Field, pp. 461-479, https://doi.org/10.1080/096543 13.2012.651800.

Steffen W. et al., Planetary Boundaries: Guiding Human Development on a Changing Planet, "Science" 2015, vol. 347(6223), https://science.sciencemag.org/content/ sci/347/6223/1259855.full.pdf (accessed: 6.05.2021). 
Steger M., The Rise of the Global Imaginary: Political Ideologies from the French Revolution to the Global War on Terror, Oxford University Press, Oxford 2019.

Taylor C., Modern Social Imaginaries, Duke University Press, Durham 2004.

Taylor C., Negative Freiheit? Zur Kritik des neuzeitlichen Individualismus, Suhrkamp Taschenbuch Wissenschaft, Frankfurt am Main 1988.

Taylor C., Philosophy and the Human Sciences, "Philosophical Papers" 1985, no. 2.

Tool M., The Discretionary Economy: A Normative Theory of Political Economy, Routledge, London-New York 2018.

Turnheim B., Kivimaa P., Berkhout F., Innovating Climate Governance: Moving Beyond Experiments, Cambridge University Press, Cambridge 2018.
Ulrich P., Lebensdienliche Marktwirtschaft [in:] Th. Bausch, D. Böhler, H. Gronke, Th. Rusche, M. Stitzel, M. Werner (eds.), Zukunftsverantwortung in der Marktwirtschaft. Festschrift für Hans Jonas, Lit, Münster 2000, pp. 70-84.

Van Vliet O. et al., Assessing Risks of Low-carbon Transition Pathways, "Environmental Innovation and Societal Transitions" 2020, no. 35, May.

Victor P., Managing Without Growth: Slower by Design, Not Disaster, 2nd ed., Edward Elgar, Cheltenham 2019.

Wahlrab A., Imagining Global Non-violent Consciousness [in:] C. Hudson, E. Wilson (eds.), Revisiting the Global Imaginary, Palgrave Macmillan, Cham 2019.

Waring M., If Women Counted: A New Feminist Economics, Harper \& Row, New York 1988. 